\title{
Ewa KEMPA
}

\section{WYBRANE PROBLEMY POLITYKI TRANSPORTOWEJ W PRZEWOZACH KADUNKÓW}

Sprawny transport jest konieczny do rozwoju gospodarczego kraju $i$ swobodnego przepływu towarów $w$ procesie globalnym. Wpływa on również na rozwój przedsiębiorczości w zakresie ustug przewozowych oferowanych przez podmioty transportowe na rynkach europejskich. W artykule przedstawiono problematykę związana z przewozem ładunków na terenie Unii Europejskiej. Zwrócono uwagę na znaczenie procesów transportowych dla gospodarki oraz konieczność zapewnienia ich bezpieczeństwa. W artykule pokazano znaczenie różnych gałęzi transportu, ze szczególnym uwzględnieniem przewozów samochodowych oraz próbowano ocenić miejsce polskich firm transportowych na tle unijnej konkurencji.

\section{WSTĘP}

Transport jest dziedzina gospodarki, którego bezpośrednie oddziaływanie odczuwalne jest przez system społeczno-gospodarczy, a systemy przewozowe, jako nieodzowny element tej dziedziny, mają różne struktury i specyfikę funkcjonowania [5, p. 290]. Dlatego organizacja przewozu ładunków jest procesem złożonym i nie polega tylko na wyborze środka transportu, ale także na wykonaniu szeregu czynności dodatkowych związanych z załadunkiem, wyładunkiem, czy obsługa całego procesu. Niejednokrotnie to właśnie one (obok kosztów) są jednym z przyczyn wyboru konkretnego rozwiazania transportowego, np. kiedy trzeba przewieźć ładunek ponagdabarytowy.

$\mathrm{Na}$ terenie Unii Europejskiej przewóz towarów odbywa się różnymi środkami transportu, ale zawsze wymagane jest dostosowanie się do przepisów prawa unijnego. Swobodny przepłtw towarów wzmógł konkurencję na rynku transportowym, gdyż zaczęły powstawać podmioty m.in. w Polsce, które w profesjonalny bezpieczny sposób zapewniaja przewóz ładunków na terenie Uni. Celem artykułu jest identyfikacja transportu jako procesu zmian zachodzących w gospodarce oraz zwrócenie uwagi na politykę transportową w Unii Europejskiej i ocena obecność polskich firm na tle konkurencji z wybranych krajów członkowskich.

\section{ZNACZENIE TROCESU TRANSPORTOWEGO DLA GOSPODARKI}

Stale rozwijajaca się gospodarka stawia przed transportem zadania wynikające z coraz większego wolumenu produkcji, specjalizacji i potrzeby globalnej współpracy. Przyczynia się to do tworzenia funkcjonalnie zintegrowanej infrastruktury, wdrażania nowych technologii transportowych oraz zapewnienia wysokiej jakości usług na konkurencyjnym rynku przewozowym [1, s. 1629].

Jednym z ważniejszych czynników kształtujących gospodarkę globalną jest konieczność przewożenia na dalsze odległości ludzi i materiałów oraz przesyłanie informacji. Transport jest obecny oraz widoczny na całej długości logistycznego łańcucha dostaw, zaczynając od pozyskiwania surowców i materiałów w procesie zaopatrzenia, aż po dystrybucję wyrobów gotowych. W gospodarce rynkowej pełni nastepujące funkcje [4, s. 187]:
- konsumpcyjna, polegającą na zaspokojeniu zapotrzebowania na transport dzięki realizowaniu zadań przewozowych,

- produkcyjna, mająca na celu zaspokojenie zapotrzebowania na usługi produkcyjne dzięki realizowaniu zadań przewozowych,

- integracyjna, polegającą na łączeniu podmiotów gospodarczych i ludzi na określonym terenie dzięki realizowanym usługom transportowym.

Każda operacja przewozowa polegajaca na przemieszczaniu ładunku z wykorzystaniem środków transportowych, wymaga pokonania kolejno nastepujących po sobie czynności, składających się na proces transportowy, co pokazano na rys. 1.

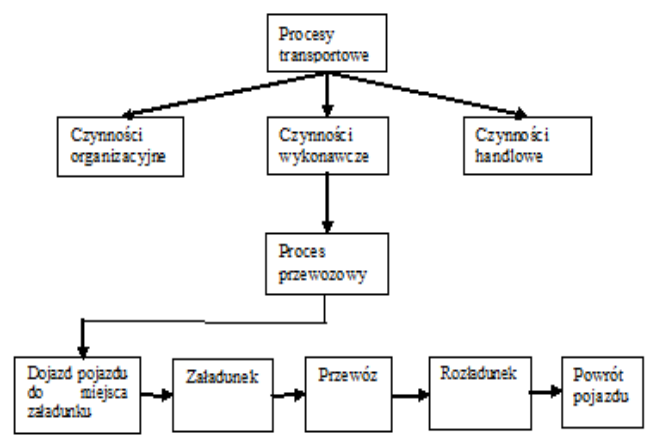

Rys. 1 Struktura procesu transportowego, [7, s. 1546]

Proces jest złożony i wielofazowy, gdyż w czasie jego trwania, przemieszczany przedmiot zwykle pokonuje wszystkie etapy procesu transportowego, w wyniku czego zostanie dostarczony w określone wcześniej miejsce docelowe. Proces transportowy jest ważnym ogniwem w łańcuchu logistycznym dostaw, łączącym klientów przedsiębiorstw, dostawców surowców oraz uczestników kanałów dystrybucji. Stanowi ciag złożonych czynności: wykonawczych, organizacyjnych oraz handlowych. Jego celem jest przemieszczenie ładunku lub ludzi z jednego lub kilku punktów nadania do jednego lub kilku punktów odbioru, przy użyciu odpowiedniego środka transportu [9, s.11].

$\mathrm{Na}$ system transportowy, składają się trzy elementy: środki transportu, infrastruktura transportu oraz system zarządzania ruchem środków transportowych przewożących towary lub osoby [2, s.273]. W każdy systemie istnieje określona liczba elementów i 
relacji zachodzących między nimi. Wśród elementów należących do systemu transportowego należy wyróżnić obiekty biorące udział w procesie przemieszczania osób i (lub) ładunków (z wyjątkiem obiektów będących przedmiotem transportu) i obiekty związane z procesem przemieszczania. Oznacza to, że do systemu transportowego należa: sieć drogowa, kolejowa, lotnicza i inne, tabor pojazdów, stacje obsługi ruchu towarowego oraz stacje i przystanki osobowe, jak również urządzenia zabezpieczenia ruchu wraz z przepisami bezpieczeństwa i kontroli ruchu. Niezbędne są również osoby, pracujące na rzecz poprawnego funkcjonowania systemu transportowego [10, s.1011].

Infrastrukturę transportową procesów logistycznych tworzy pięć podstawowych gałęzi transportu: samochodowy, kolejowy, rurociagowy, żegluga śródlądowa i morska oraz transport lotniczy [6, s. 91 92].

Ładunki towarowe w Polsce najczęściej przewozi się wykorzystując transport samochodowy. Jest on nie tylko najbardziej dostępny, ale także bardzo wygodny, gdyż można nim przewozić towary „od drzwi do drzwi”, co skraca czas i obniża koszty transportu. Nie oznacza to jednak, że nie wykorzystuje się innych gałęzi transportu. Jak kształtowała się wielkość przewozu ładunków według rodzaju transportu w wybranych latach przedstawiono w tabeli. 1.

Tab. 1.Struktura przewozu ładunków w Polsce w latach 2014 - 2016 według gałęzi transportu (mIn ton), [15, s. 316]

\begin{tabular}{|c|c|c|c|c|c|c|}
\hline $\begin{array}{c}\text { Rodzaj } \\
\text { transportu }\end{array}$ & \begin{tabular}{|c|}
2014 \\
(mln ton)
\end{tabular} & $\begin{array}{c}\text { Strukt. } \\
\%\end{array}$ & \begin{tabular}{|c|}
2015 \\
(mln ton) \\
\end{tabular} & $\begin{array}{c}2014= \\
100\end{array}$ & $\begin{array}{c}2016 \\
\text { (mln ton) } \\
\end{array}$ & $\begin{array}{c}2015= \\
100\end{array}$ \\
\hline Razem & 1840,0 & 100,00 & 1803,8 & 98,03 & 1836,6 & 101,82 \\
\hline \begin{tabular}{|l|}
$\begin{array}{l}\text { Transport } \\
\text { kolejowy }\end{array}$ \\
\end{tabular} & 227,8 & 12,38 & 224,3 & 98,46 & 222,5 & 99,19 \\
\hline $\begin{array}{l}\text { Transport } \\
\text { samochod. }\end{array}$ & 1547,9 & 84,12 & 1505,7 & 97,27 & 1546,6 & 102,71 \\
\hline $\begin{array}{l}\text { Transport } \\
\text { rurociąg. }\end{array}$ & 49,8 & 2,71 & 54,8 & 110,04 & 54,0 & 98,54 \\
\hline $\begin{array}{l}\text { Transport } \\
\text { morski }\end{array}$ & 6,8 & 0,37 & 7,0 & 102,94 & 7,2 & 104,12 \\
\hline $\begin{array}{l}\text { Śródlądowy } \\
\text { transport } \\
\text { wodny } \\
\end{array}$ & 7,6 & 0,42 & 11,9 & 156,57 & 6,2 & 52,05 \\
\hline $\begin{array}{l}\text { Transport } \\
\text { lotniczy }\end{array}$ & 0,04 & 0,00 & 0,04 & 100,00 & 0,04 & 100,00 \\
\hline
\end{tabular}

Jak wynika z powyższej Tabeli 1, najbardziej popularny w badanym okresie był transport samochodowy, gdyż obejmował ponad $83 \%$ wszystkich przewozów towarowych w Polsce i utrzymywał się mniej więcej na tym samym poziomie. Transport kolejowy, stanowiący w latach 2014-2016 ponad $12 \%$ również utrzymywał się na podobnym poziomie, jedynie w 2015 r., (podobie jak w transporcie drogowym) nastapił lekki spadek przewozu ładunków. W latach 2014-2016 transport morski obejmował jedynie poniżej $1 \%$ wszystkich przewozów, natomiast warto zauważyć, że nastapił wzrost zainteresowania tą formą transportu, gdyż w latach 2015 i 2016, wielkość przewozonych ładunków wzrastała ponad 2\% rok do roku. Transport rurociagowy, śródlądowy wodny oraz lotniczy, w badanym okresie nie odgrywały szczególnej roli w przewozie ładunków i kształtowały się na podobnym poziomie (wyjatek stanowi 2015 r). Mała popularnością wśród wszystkich rodzajów transportu w Polsce, cieszył się śródlądowy transport wodny. W 2014 r. zostało nim przewiezionych 7,6 mln ton ładunków (co stanowiło 0,42\% ogółu), w 2015 r.- 11,93 $\mathrm{mln}$ ton $(0,66 \%$ ), natomiat rok później było to zaledwie $6,21 \mathrm{mln}$ ton $(0,34 \%)$.

Popularność przewozu ładunków transportem samochodowym wynika z faktu, że charakteryzują go pewne cechy zwiększające jego konkurencyjnośc w stosunku do innych rodzajów transportu. Do tych cech można zaliczyć [11, s.145]:
- dużą łatwośc docierania w dowolne miejsce, zgodnie z zasada „od drzwi do drzwi”

- znaczną operatywność usługową, wynikająca z dyspozycyjności taboru,

- dużą elastyczność w dostosowaniu się do potrzeb klienta. Ograniczenia w korzystaniu $z$ infrastuktury transportowej sa niższe niż w przypadku innych rodzajów przewozu,

- relatywnie dużą szybkość przewozu (zwłaszcza w transporcie średniego i krótkiego zasiegu),

- niezawodność obsługi, a zwłaszcza punktualność wykonywania usług (przy założeniu braku zakłóceń na trasie przewozu).

Liczne inwestycje w infrastukturę transportowa, które w ostatnich latach mają miejce w Polsce wpływają na lepszają jakość przewozów. Szczególnie widoczne jest to w transporcie drogowym, co dodatkowo zwiększa jego populatność. Nie bez znaczenie są również ograniczenia na szlakach wodnych i kolejowych oraz koszty, które np. w transporcie lotniczym są wysokie, co zapewne wpływa na wykorzystanie go do przewozu ładunków.

\section{BEZPIECZEŃSTWO W PRZEWOZIE ŁADUNKÓW}

Transport jest obecny własciwie na każdym etapie funkjonowania przedsiębiorstwa, ale najbardziej widoczny jest podczes przewozu ładunków w procesie zaopatrzenia i dystrybucji. Szybkość i sprawność transportu staje się priorytetem, przy którym zapomina się o jego negatywnych stronach. Współczesna gospodarka nie może funkcjonować bez transportu, który zapewnia dostarczenie ładunku w odpowiednie miejsce, ale jednocześnie generuje duże koszty zewnętrzne (społeczne), na które składają się następujące czynniki [3, s. 278-279]:

- zwiększone stężenie zanieczyszczeń (smog) spowodowane, np. wydzielaniem spalin,

- emisja hałasu przez środki transportu, co niekorzystnie wpływa na zdrowie ludzi, ale także zwierząt,

- zajęcie terenów przez infrastrukturę transportową, co często odbywa się kosztem flory i fauny,

- koszty utrzymania infrastruktury transportowej, będące poważnym obciążeniem dla każdego budżetu, np. gminy, czy miasta,

- zmiany klimatyczne (globalne ocieplenie) spowodowane zanieczyszczeniem środowiska,

- wypadki komunikacyjne. Ich prawdopodobieństwo wzrasta przy większym natężeniu ruchu spowodowanym $\mathrm{np}$. ograniczeniem czasu przewozu ładunków,

- kongestia, czyli brak płynności ruchu środków transportu spowodowanych różnymi przyczynami występującymi w logistyce miejskiej.

Rosnące wymagania klientów związane z otrzymywaniem przesyłek powoduja, iż podmioty logistyczne chcąc spełniać te oczekiwania muszą utrzymywać wysokie standardy swoich usług. Z perspektywy sprzedawców detalicznych szybkość dostawy nadal ma duże znaczenie, gdyż konsumenci moga zrezygnować z zakupu, jeśli dostawa będzie trwała zbyt długo. Wpływa to na rozwój nowych opcji dostawy i modeli procesów biznesowych. Należy jednak pamiętać, że konsumenci nadal wolą niskokosztowe modele dostawy z możliwością bezproblemowego zwrotu zakupionych towarów [14].

Intensywność przewozów ładunków transportem kolejowym, narastające zatłoczenie na drogach, zmienne warunki pogodowe oraz prawdopodobieństwo wystapienia zjawisk niekorzystnych na drogach oraz innych szlakach transportowych, powoduje konieczność zadbania o bezpieczeństwo przewozów. Dlatego coraz częściej w pojazdach stosuje się urządzenia, które w połączeniu z innymi technikami i technologiami stanowia system ustalania pozycji i danych pojazdu, pozwalających na [8, s.176-177]: 
- automatyczne przekazywania informacji o trasie przejazdu (stały monitoring),

- odnalezienie pojazdu, który np. został skradziony,

- zdalne unieruchomienie pojazdu (jeżeli zaistnieje taka konieczność),

- przekazywanie odpowiednim służbom informacji o transporcie materiałow niebezpiecznych, w celu ograniczenia prawdopodobieństwa katastrofy i zapobiegania jej skutkom,

- optymalizowanie kosztów przewozowych (dane o prędkosci, czasie pracy, postojach oraz planowanie tras przejazdu),

- zarządzanie przewozami w trybie on-line (eliminowanie pustych przebiegów i niewykorzystanej powierzchni ładunkowej, mozliwość szybkiej reakcji w przypadku kradzieży lub wypadku),

- efektywne wykorzystanie środków transportu i potencjału ludzkiego (przygotowanie w odpowiednim czasie rozładunku oraz szybkie reagowanie na zaburzenia $w$ planowaniu transportu).

W praktyce do monitorowania ruchomych środków transportu wykorzystuje się satelitarny, globalny system pozycjonowania GPS (Global Positioning System), w połączeniu z pakietową transmisja danych GPRS (General Packed Radio System) oraz GSM (Global System of Mobile Communication) cyfrowej telefonii komórkowej działajacej na częstotliwosci $900 \mathrm{MHz}$ [8, s. 177].

Warto również wspomnieć, że np. na poprawę bezpieczeństwa w ruchu drogowym maja wpływ: obowiazkowe zapięcie pasów, poduszki powietrzne, światła drogowe przez cała dobę, duża liczba fotorejestratorów, opony zimowe, ABS itp. Pomaga to w swobodnym przemieszczaniu się innych uczestników ruchu i przyniosło już zauważalne efekty w postaci obniżenia wskaźników liczby ofiar.

\section{KIERUNKI PRZEWOZU ŁADUNKÓW TRANSPORTEM DROGOWYM}

Na rynku polskim istnieje wiele firm transportowych, których oferta obejmuje nie tylko teren naszego kraju. Obecność Polski w Unii Europejskiej daje większe możliwości konkurowania na rynkach europejskich, pobudza również konkurencję zagraniczna. Dlatego w dzisiejszych czasach podmioty transportowe stoją w obliczu dużych wahań popytu i wysokich kosztów stałych na konkurencyjnych rynkach [12, s. 149]. Chcąc obniżyć koszty i zwiększyć elastyczność usług, spedytorzy ograniczają tzw. „puste przewozy” oraz zawieraja umowy z podwykonawcami zewnętrznymi. Najczęściej stosuje się to $w$ transporcie samochodowym, gdzie dostęp do infrastruktury jest łatwiejszy, a przewozy nie zawsze dokonywane sa tylko w celach zarobkowych, ale również dla celów własnych, np. na potrzeby zaopatrzenia. Jaka była struktura przewozu ładunków transportem drogowym w latach 2014 - 2016 przedstawiono w tabeli 2.

Tab. 2. Struktura przewozów ładunków przez polskie firmy transportem samochodowym według kierunku transportu w latach 2014-2016 (\%) [16,s.169]

\begin{tabular}{|l|l|l|l|l|l|l|}
\hline \multirow{2}{*}{ Kierunki Transportu } & \multicolumn{2}{|c|}{2014} & \multicolumn{2}{c|}{2015} & 2016 \\
\cline { 2 - 7 } & $\mathrm{Z}^{*}$ & $\mathrm{G}^{* *}$ & $\mathrm{Z}^{*}$ & $\mathrm{G}^{* *}$ & $\mathrm{Z}^{*}$ & $\mathrm{G}^{* *}$ \\
\hline OGÓŁEM & 66,77 & 33,23 & 70,03 & 29,97 & 72,16 & 27,84 \\
\hline Transport krajowy & 61,88 & 38,12 & 65,11 & 34,89 & 66,71 & 33,29 \\
\hline $\begin{array}{l}\text { Transport międzyna- } \\
\text { rodowy }\end{array}$ & 95,95 & 4,44 & 95,56 & 4,44 & 96,21 & 3,79 \\
\hline Eksport & 91,92 & 9,08 & 91,96 & 8,04 & 93,53 & 6,47 \\
\hline Import & 94,02 & 5,98 & 94,41 & 5,59 & 94,75 & 5,25 \\
\hline $\begin{array}{l}\text { Transport pomiędzy } \\
\text { obcymi krajami }\end{array}$ & 98,43 & 1,57 & 99,35 & 0,65 & 99,27 & 0,73 \\
\hline Kabotaż & - & - & 98,25 & 1,75 & 98,31 & 1,69 \\
\hline
\end{tabular}

$Z^{*}$ - Przez transport samochodowy zarobkowy rozumie się świadczenie usług przewozowych za opłata.
$G^{* *}$ - Transport samochodowy gospodarczy, to wykonywanie przewozów ładunków na własne potrzeby, tj. bez opłat (wliczanych w koszt przedsiębiorstwa),

W badanych latach, przewózy ładunków transportem samochodowym odbywały się głownie w celach zarobkowych, co widać w tabeli 2. Transport gospodarczy, czyli związany z własnymi potrzebami przebiegał najczęściej na terenie kraju i w latach 20142016 wynosił ponad 33\%. W okresie 2015-2016 (w 2014 brak danych) polskie firmy przewozowe świadczyły swoje usługi, często na terenie obcego kraju, np. stosując kabotaż. Ponad $90 \%$ przewozów na trasach międzynarodowych odbywało się w celach zarobkowych, co potwierdza jedynie, że polskie firmy transportowe są coraz lepiej przygotowane do obecnosci na rynkach europejskich i moga skutecznie konkurować z tamtejszymi podmiotami.

\section{PRZEWÓZ ŁADUNKÓW TRANSPORTEM SAMOCHODOWYM}

Kraje Unii Europejskiej potrzebują spójnej polityki transportowej, pozwalajacej wspierać handel i rozwój gospodarczy, tworzyć miejsca pracy oraz zapewnić bezpieczne przemieszczanie się ludzi oraz efektywną dystrybucję towarów. Obowiązujące w całej Unii Europejskiej jednolite zasady dotyczace maksymalego czasu pracy $i$ minimalnego czasu odpoczynku wszystkich kierowców pozwalaja na korzystniejsze planowanie tras przewozowych.

Najbardziej popularnym sposobem przemieszczania ładunków w Europie jest transport drogowy. Większość transportu śródlądowego towarów w Unii Europejskiej odbywa się po drogach, a sektor ten stale rośnie. Jak wyglądały przewozy ładunków transportem samochodowym w latach 2012-2016 w wybranych krajach Unii Europejskiej pokazano na rys. 1.

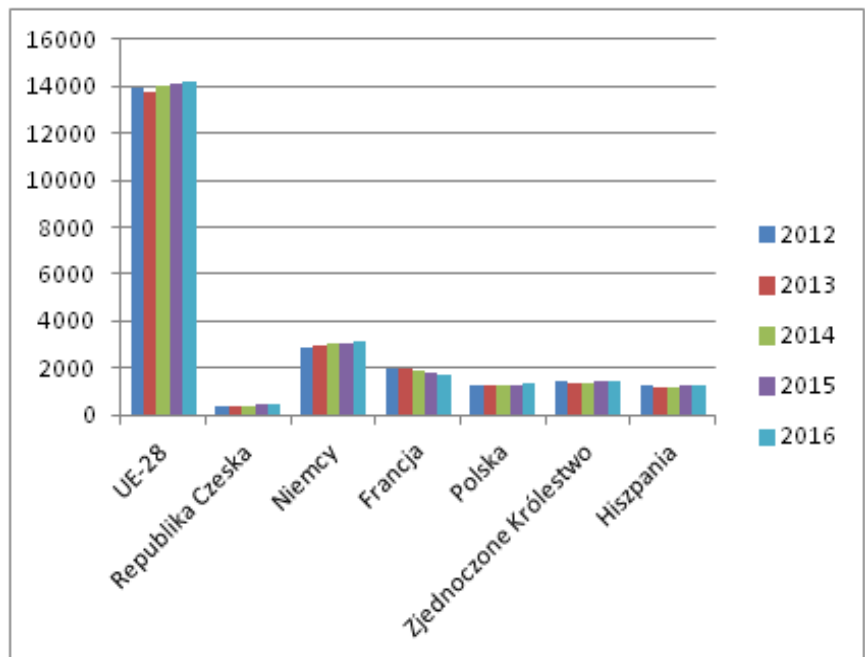

Rys. 1 Transport drogowy towarów (lata 2012-2016) w wybranych krajach UE (tys. ton)

Źródło: opracowanie własne [13]

Na powyższym rys. 1 widać, że drogowy transport towarów na terenie Unii Europejskiej powiększa się z roku na rok, co tylko potwierdza jego popularność. Wśród badanych krajów, najwięcej towarów zostało przewiezionych przez przewoźników z Niemiec, Francji, Zjednoczonego Królestwa oraz Polski, a najmniej z Republiki Czeskiej. W latach 2012-2016 sukcesywnie zwiększał się przewóz ładunków w Niemczech oraz w Polsce. W 2016 r. w stosunku do 2012 r. ilość ta wzrosła w Niemczech o około 8\%, a w Polce o około 5,5\%. W Zjednoczonym Królestwie i Hiszpanii, przewóz ładunków transportem samochodowym w badanych latach 
kształtował się na porównywanym poziomie. Pomimo, że przewóz ładunków przez przewoźników z Republiki Czeskiej między 2012 i 2016 rokiem wzrosł o ponad $27 \%$, to jednak ciagle stanowi to niewiele ponad $2 \%$ w stosunku do całej Unii. Wyniki te pokazują, że polskie firmy transportowe są nie tylko obecne na rynku europejskim, ale również moga skutecznie konkurować z podmiotami z Europy Zachodniej.

Popularność przewozu ładunków transporem samochodowym wynika zapewne z jego dostępności i udzału w transportach kombinowanych, ale również $z$ dużymi nakładami na rozwoju infrastruktury drogowej. Pomimo stale zmieniających się przepisów prawa i zwiększonych wymogów bezpieczeństwa, z roku na rok przybywa firm transportowych świadczących usługi drogowe w Polsce i za granica. Słabsza popularność pozostałych gałęzi transportu wynika z ich mniejszej dostępności, ograniczeń prawnych i niższych nakładów na infrasturuturę.

\section{PODSUMOWANIE}

Transport, pomagając w łączeniu rynków odgrywa istotne znaczenie w rozwoju globalnych stosunków gospodarczych. Niezbędne jest inwestowanie w nowoczesna infrastrukturę transportowa, która usprawni proces przewozowy i zwiększy jego bezpieczeństwo, jednocześnie pozwalając osiagnąć zamierzone cele gospodarcze.

Wychodząc naprzeciw tym potrzebom i oczekiwaniom opracowano Strategię Rozwoju Transportu do 2020 r., w której wyznaczono kierunki i plan działań „w zakresie tworzenia w Polsce nowoczesnego, efektywnego i bezpiecznego systemu transportowego, który będzie stwarzał nowe impulsy rozwojowe gospodarce narodowej". Celem strategii jest usunięcie istniejących barier i tworzenie nowej jakości w zarządzaniu, infrastrukturze transportowej i systemach transportowych [17, s. 110], co jest sukcesywnie realizowane.

Przewoźnicy drogowi w Unii moga prowadzić działalność nie tylko w kraju swojej rejestracji, co pozwala im uniknać przejazdów powrotnych pustym pojazdem. Przeprowadzone badania pokazały, że polska branża samochodowa dobrze wykorzystała swobodny przepływ towarów i usług obowiązujący w Unii Europejskiej, inwestując w wysokiej jakości tabor transportowy, a przede wszystkim konkurując niższymi kosztami. Z czasem polscy przewoźnicy zbudowali u swoich europejskich klientów zaufanie i pewność solidnego wykonania usługi, dzięki czemu Polska stopniowo, ale konsekwentnie staje się znaczącym partnerem w europejskim transporcie drogowym i może skutecznie konkurować z liderami na rynku.

\section{LITERATURA}

1. Bujak A.: Nowe uwarunkowania funkcjonowania transportu drogowego w Europie, Autobusy 6/2017.

2. Kwaśniowski S.; Transport, w: Logistyka. Teoria i praktyka, pod red.: S. Krawczyk, Difin 2011.

3. Nowoczesne technologie w logistyce; pod red.: J. Długosz, PWE, Warszawa 2009.

4. Pisz I., Sęk T., Zielecki, w.: Logistyka w przedsiębiorstwie, PWE, Warszawa 2013.
5. Pyza D, Miętus M.; Organizacja przewozu ładunków transportem drogowym z uwzględnieniem różnych technologii przewozowych, Prace Naukowe Politechniki Warszawskiej. Transport, $117 / 2017$.

6. Skowronek Cz., Saryusz - Wolski Z., Logistyka w przedsiębiorstwie, PWE Warszawa 2012.

7. Starkowski D.; Analiza procesu transportowego na przykładzie wybranego przdsiębiorstwa transportowo-spedycyjnego podczas przewozu truskawek. Część druga - teoretyczne zasady planowania operacji przewozowej. Autobusy 6/2017,

8. Szymonik A., M. Bielecki: Bezpieczeństwo systemu logistycznego w nowoczesnym zarządzaniu, Difin Warszawa 2015.

9. Wojtynek L., Kulińska E., Masłowski D., Dendera-Gruszka M., Juranek K.; Planowanie, organizowanie i koordynowanie transportu ponadgabarytowego $w$ przedsiębiorstwie, http://www.ptzp.org.pl/files/konferencje/kzz/artyk_pdf_2017/T2/t 2_108.pdf

10. Żak J; Parametryzacja elementów procesu transportowego, Logistyka, 4/11.

11. Żak J.; Transport w: Logistyka, pod red. D. Kisperska-Moroń, S. Krzyżaniak, Biblioteka Logistyka, Poznań 2009.

12. Ziebuhr M. , Kopfer H.; Solving an integrated operational transportation planning problem with forwarding limitations, Transportation, Research Part E: Logistics and Transportation Review, Volume 87, March 2016, DOI,.org/10.1016/j.tre.2016.01.006.

13. http://ec.europa.eu/eurostat

14. www.logistyka.net.pl

15. Mały rocznik statystyczny GUS 2016-2017.

16. Transport. Wyniki działalności w 2016 r., GUS, Warszawa, https://stat.gov.pl/

17. Strategia Rozwoju Transportu do 2020 (z perspektywą do 2030r.) http://prawo.sejm.gov.pl/

\section{Selected problems of transport policy in the carriage of cargo}

Efficient transport is necessary for the economic development of the country and the free flow of goods in the global process. It also affects the development of entrepreneurship in the field of transport services offered by transport entities on European markets. The article presents the problems related to the carriage of cargo within the European Union. Attention is paid to the importance of transport processes for the economy and the need to ensure their safety. The article shows the importance of various modes of transport, with particular emphasis on road transport and tried to assess the position of Polish transport companies against the background of EU competition.

\author{
Author \\ dr Ewa Kempa - Politechnika Częstochowska, Wydział Zarzą- \\ dzania.
}

JEL: R48 DOI: 10.24136/atest.2018.228

Data zgłoszenia: 2018.05.28 Data akceptacji: 2018.06.15 